\title{
Incubation Activities and Entrepreneurship: Does it Work Together?
}

\author{
Petra Tausl Prochazkova
}

\author{
University of West Bohemia, Faculty of Economics, Pilsen, Czech Republic
}

Correspondence should be addressed to: Petra Tausl Prochazkova; pprochaz@kpm.zcu.cz

Received date: 21 April 2014; Accepted date: 17 July 2014; Published date: 2 September 2015

Academic Editor: Constantin Ilie

Copyright @ 2015 . Petra Tausl Prochazkova . Distributed under Creative Commons CC-BY 4.0

\begin{abstract}
It is widely believed that entrepreneurship is an engine of nowadays economic and that entrepreneurial activities should be supported as much as they can be. As one of their support way have been recognized business incubation models. Business incubators are considered as a valuable source of nurture of new entrepreneurial ventures. Especially, fresh entrepreneurs are in focus of major support program politics because each start-up is very delicate and risky matter and should be supported by special business development services. It is clear, that it is spoken primarily about small and middle sized enterprise (SME) sector that has emerged as the most dynamic and turbulent part of national economics. Therefore, SME entrepreneurial activities are seen as the main source of economic development and global competitiveness. Naturally, SME activities are so in the center of business incubation focus. However, an essential question should be asked: Does it work? Is the incubation support system well-structured and helpful for entrepreneurship activities? There has been observed a slight tendency to let incubation activities escape by systematic review due to lack of data. To clarify this issue, an observation of chosen incubator samples was carried out. The cornerstone of this observation was structured on the existing body of knowledge of the area of business incubation and its relation to entrepreneurship. This study uses a two-ways approach: first approach is focused on discussing gained data from the carried out observations and its comparison to the already existing data. Second approach is focused on demonstrative examples of best practices.
\end{abstract}

Keywords: incubators, entrepreneurship, SMEs, observation

\section{Introduction}

There is no doubt that entrepreneurship is considered as the engine of economic growth, new work places and competitiveness. It is viewed as multidimensional concept in which conditions are changing thanks to globalization and dynamic economic environment. Nowadays, economic development offers a lot of positive challenges to the development of SMES but on the other hand it is highly competitive environment which requires well prepared individuals. To survive and to seize these opportunities, today's entrepreneurs are forced to develop innovative products, efficient production techniques and

Cite this Article as: Petra Tausl Prochazkova (2015)," Incubation Activities and Entrepreneurship: Does it Work Together? ", Journal of Eastern Europe Research in Business and Economics , Vol. 2015 (2015), Article ID 436040, DOI: 10.5171/2015.436040 
management for sustainability of their units. The pace of information spreading is increasing as well as the time for its use. Entrepreneurs cannot allow not having right information at the right place. It is true that entrepreneurship is the essence of economic development. Indeed, in today's environment it can only hardly exist without various initiatives which enable to create environment for innovation and entrepreneurship such as business incubators, science parks initiatives. These entrepreneurial support institutions foster interactions between enterprises, industry and often academic sphere for sharing ideas, experience and making business idea alive. There is, especially in the developed countries, an increasing attention paid to the potential of business incubation activities to facilitate enterprises development, especially SMEs development (Galloway, Brown, 2002). It is believed that such potential can be realized in a long-term view. To be sure that the trend has the right direction, there should be provided some systematic review of such activities regularly. It is essential to assess how important the role of incubators for entrepreneurship development is and in the wider business world in general, and how incubators meet the needs and wishes of clients and stakeholders as well (European Union, 2010). Currently, there might be a tendency to escape such observation especially in countries with shorter history. As an example of such a country the situation in the Czech Republic (CZ) can be used. Czech Republic can be still considered a novice in this area. Observations of existing incubators abroad and its comparison to home situation can bring valuable source of information which can fit as another piece of puzzle into the whole piece.

\section{SMEs Challenges in General}

SMEs, competitiveness, sustainability and innovation have become buzzwords recently. SMEs have the ability to hold the economy, business and countries on the "safe side". Since the 80's of the last century, SMEs importance has rapidly increased and they become a center of each government economy strategy (Richard, 2008). Such boom interest in SMEs activities is explained by many experts for example by Audretsch (1995) who sees SMEs as agents of change who are the driving force of economy. Or by Lucas (1978) who considers SMEs as a quite cheap tool for identification of entrepreneurial and managerial potential. As it is well known, on the way to SMEs' success there are many obstacles that need to be fought. The most widespread facts are for example: difficulty with capital accessibility, administrative bureaucracy, government policy (such as taxation, business environment conditions), lack of skills, experience, entrepreneurial education or just access to information (Tausl Prochazkova, 2012; European Commission, 2008; Januska et al., 2010).

To support SMEs activities there are several options to be used. Almost each government recognizes their ability to generate economic values and sets up variable tools of their support. Next to the classic direct tools with financial character there is a certain focus on indirect tools mainly related to offering complex services. One option which combines directly several support possibilities is a concept of business incubator. Business incubation presents a modern method how to help the start-up entrepreneurs to survive and develop their business. It can be considered as a widely spread method whose system of evaluation is still a little bit patchy, mainly in countries where the history is shorter.

Furthermore, it is necessary to mention that SMEs are currently in an interesting position. They are undergoing significant shifts which are simultaneous to national, or more precisely, to the world economy. In order to survive and enable the growth of their ventures they should be more flexible, energetic and tireless by running their businesses. Competitiveness is one of the key words in today's globalized world which they need to pay attention to. World Economic Forum defines competitiveness on an example of twelve pillars set up as a set of institutions, policies and factors which determine the level of productivity 
of a country. The twelve pillars present the most important factors which may be helpful by making SMEs life easier. They are for example: institutional environment, infrastructure conditions, higher education and training, business sophistication or innovation. In other words, competitiveness means how countries create the best economic, social and environmental conditions for their economic development. Striving for competitiveness is striving for raising prosperity (Schwab, 2013). The level of competitiveness depends on the interaction between several factors as named above including other critical factors, such as the availability and quality of educational opportunities.

Another specific challenge speaking about SME position and its role in the economy is its ability to contribute to business sustainability. Business sustainability is the inclusion of financial, environmental and social concerns into business decisions. SMEs are impacted by the global context and current conditions of business environment to integrate sustainability into their core businesses (Horova, 2012). But to find those sustainability objectives can sometimes pull them in several different directions (Network for Business Sustainability, 2013). There might be a question, how SMEs can maintain competitiveness and contribute to sustainability? Flexibility, knowledge and innovation are the essential answers to their survival. Through innovation, SMEs can serve as a lever for environmental protection and create social value (Network for Business Sustainability, 2013).

Clearly said, SMEs face many challenges from their birth. Not only do they need to prove they are able to handle traditional problems of this sector, but in addition they are still more in touch with competitiveness and sustainability topic in general.

\section{Incubation Enables Enhancement of Business Ideas}

As it was previously mentioned, to struggle the obstacles and survive on the market SMEs can use various help. In general, there are several opinions among the experts in the business support system. Some experts have doubts about the appropriateness of the support scheme. One is speaking for all. Sobel (2008) refers to a side effect of the support scheme in order to tend SMEs into the change of their original entrepreneurial activities just because of getting some support. On the other hand, for example Moly (2004) sees every SME as an individual entrepreneur whom a tailored help should be offered. Parker (2009) stresses that each SME has the right on information but unfortunately not each SME has all available information. However, SME can use an appropriate way of help to reduce the lack of information. Furthermore, he pointed out the question of first mover and free riders. To minimize the first mover's costs and support his/her enthusiasm, a business support tool can be also used. Last, but not least, Storey (1994) mentions an essential reason for help and those SMEs present a valuable source of added value and employment.

The trend of several last years is a phenomenon of business incubator. To be more precise business incubation history depends on the destination. In Europe it is the history dated back approximately between $70-80$ 's of the last century in countries such as United Kingdom, France or Germany (OECD, 1999). In the Czech Republic the biggest boom of business incubation model is a task of the last 10 years. First incubation effort appeared in 90 's of the last century but the biggest boom has been recognized since 2005. In the Czech Republic, business incubators started to appear very often. Such development has been accompanied by the development of science parks and in the last few years accelerators become popular too. Generally, it is difficult to give an exact number of business incubation institutions in the Czech Republic. Perhaps, the most accurate number can be found thanks to the Science and Technology Parks 
Association in the Czech Republic which state currently 43 institutions. Unfortunately, some of the incubators existing in the Czech Republic do not fulfill their mission and are likely to be seen as developer projects.

Obviously, business incubation core is created by attempts to help the would-be and start-up entrepreneurs thanks to various assistance offers. As definitions of entrepreneurs differ, the same is truth for business incubators. Kuratko and LaFollette (1987) see incubators as a subject effectively collecting know-how, talent and technologies in order to support the start-up entrepreneurs. CSES (2002) characterizes them as an organization which enables and organizes development of new ventures thanks to a transparent overview of business support such as office space, networking, and consultancy. Based on EU (European Union, 2010) such services can be divided into 3 groups:

- Pre-incubation - activities necessary for supporting the potential entrepreneur in developing his business idea.

- Incubation - support provided to the entrepreneur from the start to the expansion phase, typically physical incubation, mentoring, training, networking etc.

- Post-incubation - relates to the activities to be carried out when the company has reached its maturity phase.

Incubators mission can be clearly summarized in words: facilitate, enable, support and develop. In praxis several types of incubators exist. Based on Aernoudt (2004) and CSES (2002) typology, in the Czech Republic the majority has traditional characteristics, non-profit, technology or research type with relationships to university. Furthermore, Lalkaka (1999) and CSES (2002) sum up the basic aims of such incubation concepts into several tasks:

- Assistance for higher survival rate of new ventures,

- Establishment and development of new ventures,
- Decrease of incubated enterprises costs,

- New work places,

- Raising of national (regional) competitiveness.

Wilber a Dixon (2003) describe their main aim of incubator in their care of such entrepreneurial project which have potential to be viable.

As an indication of their usefulness many new incubators have been established in the last few years. However, such indication may be not considered as a sufficient argument for the evaluation of their impact on economy. Nowadays, the methodologies for assessing and benchmarking incubators impact on SMEs performance and competitiveness are emerging (Lalkaka, Rustam, 2000). There might be a question: How do business incubators in reality contribute to the growth of SMEs? Are they truly able to help the start-up of SMEs to stand on their own feet?

\section{Benchmarking Observations}

The aim of author's research is to outline the gained data about incubators observation in the Czech Republic and if possible confront these data with relevant observation provided in the EU (mostly with benchmarking character). It must be mentioned that there is a lack of complex incubation evaluation studies and possibly the most transparent one was published by Centre for Strategy and Evaluation Services (CSES, 2002). This study is comprised of combination of 2 approaches. First, data from the carried out observations, secondly examples of the best practices chosen issues. It is important to highlight that the ambition of this paper is not to offer a complete analysis of the provided research. Rather, the author focuses on stressing chosen parts of the research including links to another author's papers with further results of the research.

Two observations were made during the years 2011/2012. These observations were completed by expert discussions from stakeholders' range of incubators. First 
research was carried out by 12 business incubators from addressed 29 and has been added by expert discussions with incubators managers. It must be mentioned that these incubators present mainly the incubation core in the Czech Republic. Second observation was made by tenants and by graduates companies. 78 clients were asked, 28 answered - all SME sector, mainly active in IT, marketing or other technical branches.

As Lalkala (2000) or CSES (2002) mentioned, there are several groups of information to be followed regarding the evaluation of incubator activities. The range of such information is wide. Evaluation can be started by general matters such as - assessing quality and quantity of offered spaces, number and qualification of incubator employees, offered service, number of tenants, incubated firms, generated jobs, growth of incubated firms profit, sales and employees, etc. Following, there is information provided to some of the selected topics.

\section{Observations: Basic Information and Services}

When starting the observation with basic information it must be considered that in the Czech Republic are in average only 3 employees active in incubation services in comparison to EU average, 5, 6 people. Incubator management possesses usually $(80 \%)$ economic or technical education which is comparable to EU situation (74,5\%) (CSES, 2002). Experts recommend
(Lalkaka, Rustam; Abetti, Pier A., 1999) incubators employees to have previous experience in entrepreneurship. Such recommendation is hardly achievable in Czech conditions.

Speaking about premises, Czech incubators are mainly situated in reconstructed premises (58\%) compared to EU where new premises are typical $(60,3 \%)$. The average incubator space is $3573 \mathrm{~m}^{2}$ from which clients can use in average $2682 \mathrm{~m}^{2}$. EU standards are higher by $5860 \mathrm{~m}^{2}$. The lack of space then results in Czech incubators not being able to offer wider choice of special premises - such as laboratories, storehouses, etc. As it was mentioned in the previous text, in the Czech Republic several new incubators buildings were established thanks to EU programs. Some of them were labelled during experts discussions as mainly developer issues hardly achieving the primary purpose of incubator existence.

One of the essential indicators should be the rate of occupancy. By the examined sample, a rate reached $90 \%$ which is a great number also in comparison to $\mathrm{EU}$ 85\% (CSES, 2002). Basic information, which every incubator should try to publish ,are numbers of tenants, graduates, created work places or ability of tenant to create a profit, raise sales. However, some institutions still do not follow these data; even they do not publish them in an annual report. This fact does not support entrepreneurial enthusiasm properly. An overview of gained data is presented in table 2 (own source, 2012).

Table 1: Basic published incubator information

\begin{tabular}{|l|c|c|c|c|}
\hline & $\begin{array}{c}\text { Number of } \\
\text { incubated clients } \\
\text { since incubator } \\
\text { establishment }\end{array}$ & $\begin{array}{c}\text { Number of created } \\
\text { work places since } \\
\text { incubator } \\
\text { establishment }\end{array}$ & $\begin{array}{c}\text { Actual number } \\
\text { of incubated } \\
\text { clients }\end{array}$ & $\begin{array}{c}\text { Graduate } \\
\text { clients }\end{array}$ \\
\hline Average & 38,3 & 163,3 & 21 & 12 \\
\hline
\end{tabular}

The table shows that in average in each incubator there are 21 clients in comparison to the EU average 30 (CSES, 2002). A positive effect can be seen on the answer of incubated clients. More than
$50 \%$ confirms that during their incubation their number of employees and turnover has increased. However, they were not able to report exact number of annual increase. Finally, an essential question regarding 
incubator importance to SMEs was asked. It was proved that incubator activities really make SMEs start-up easier (all respondents agree) where $68 \%$ value these activities as very important (Tausl Prochazkova, 2012).

Furthermore, figure 1 presents how incubators aims correspond to the general mission of an incubator (Tausl Prochazkova, 2012), (own source, 2011). The results correspond to the observation in EU (CSES, 2002). It must be considered that incubator aims correspond to the primary purpose of their existence and that they help SMEs in their activities and raise their competitiveness in that way.

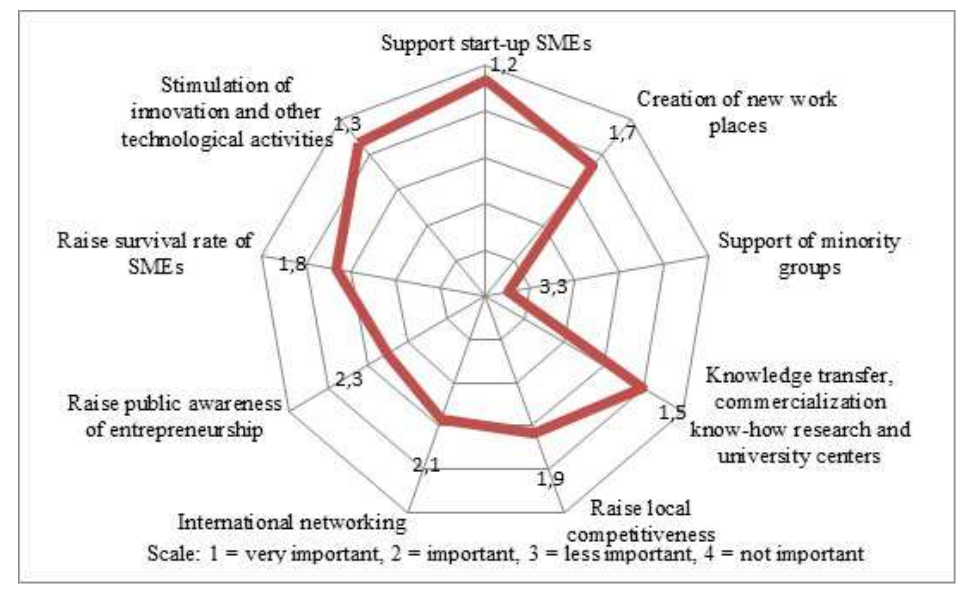

Figure 1: Incubators aims

Incubator services have to correspond with the settled aims. The highest interest is still in possibilities using spaces, following with other offered services which are presented in the figure 2 (Tausl Prochazkova, 2012).

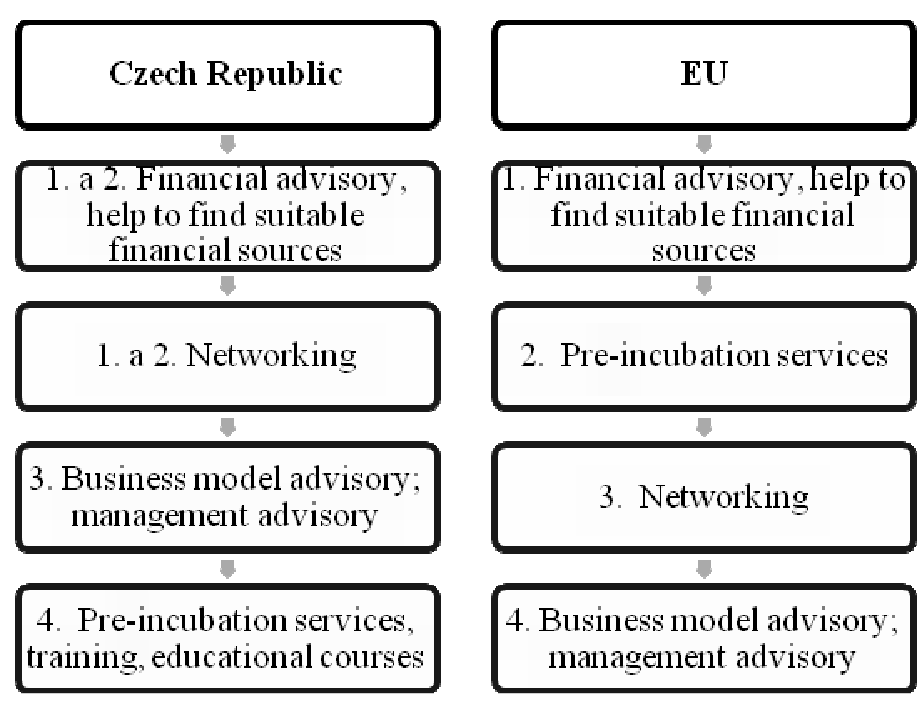

Figure 2: 4 most common offered services by incubators

A complex view on incubator services completes the view of incubated clients. Incubator clients have valued the most four important services (except of using incubator spaces) and their opinion was compared to the services which most of Czech incubators offer. As previously stated, clients still value as number 1 the 
possibility to use incubator spaces. Then most valued services (in the rank from first place to fourth place) are networking; training, educational courses; marketing advisory and business model and management advisory. Comparing with figure 2, to the most offered services by incubator, the preferred services are the same only with different preferences scale.
Speaking about incubator services and their aim would be essential and helpful to compare if the set of mainly spread offered services answer the problematical issues of SMEs. In table 2 are summarized the most disadvantages of SMEs and compared with suitable incubator services which can help to minimize these problems. As it is seen, from this point of view, the structure of incubator seems to be well settled.

\section{Table 2: Spectrum of incubator services and problematical issues of SMEs}

\begin{tabular}{|l|l|}
\hline \multicolumn{1}{|c|}{ Spectrum of incubator services } & \multicolumn{1}{c|}{ Problematical issues } \\
\hline $\begin{array}{l}\text { Financial advisory, help to find suitable } \\
\text { financial sources }\end{array}$ & $\begin{array}{l}\text { Lack of financial capital, lack of information about } \\
\text { financial issues, sources }\end{array}$ \\
\hline Networking & Lack of business relations and costumers \\
\hline $\begin{array}{l}\text { Business model advisory, management } \\
\text { advisory }\end{array}$ & $\begin{array}{l}\text { Weak business model, business strategy, lack of } \\
\text { information }\end{array}$ \\
\hline Training, education courses & Insufficient experience and knowledge \\
\hline Marketing advisory, market research & Week information about market, too much \\
optimistic view about market, costumers etc.
\end{tabular}

Speaking about incubator services, "table 3 " is summarizing the best practices in chosen services - networking and financial services (own source, 2012, 2013), (Wolf et al., 2000), (CSES, 2002), (Growlink, 2011).

Table 3: Best practices in networking and financial services

\begin{tabular}{|l|l|}
\hline \multicolumn{3}{|c|}{ Examples of Best Practices - Services } \\
\hline Networking - CZ & \multicolumn{1}{|c|}{ Networking - Abroad } \\
\hline There is no such system as for example in & In the EU generally high importance is \\
Sweden (Growlink) in the Czech Republic. & assigned to networking. Such example can be \\
Each incubator possesses its contact & the Growlink system in Sweden which is a \\
databases, but nothing in particular. Most & networking system not only for business \\
common activity is the participation in some & partners, but also for mentors, training \\
international network such as Enterprise & providers, financial institutions, etc. \\
Europe Network or Microsoft BizsPark & Inthe USA it is quite common term Brown Bag \\
Network which is not a guarantee for good & Lunch Program-a regularly arranged meeting \\
networking system. Probably the most & with graduates clients, investors, business \\
\hline
\end{tabular}


common are events such as conferences with special topic - for example conference organized by Inova center are quite well known

\begin{tabular}{|l} 
Financial services - CZ \\
\hline Within the Czech conditions the main core is
\end{tabular} still only financial advising. Indeed, there are first pioneers such as South Moravian Innovation Centre (JIC) which probably came first with a system of innovation vouchers.

professionals, etc.

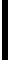

In the EU there have been slowly widen additional forms of financing such as seed capital. Good example is the Centre for Advanced Technology in Denmark or Business Innovation Center in Dublin. Perhaps, the still most spread is only financial advising of incubators, but the importance and call for these forms is gradually increasing.

\section{Observation: Entrance Policy}

Each incubator has to create its own entrance policy in order to differentiate between viable and not viable business projects. The most common criteria are described in figure 3. The most important criteria are a personal meeting and consultation of business plan with representatives of business incubator. In comparison to EU study (CSES, 2002), it is surprising that in this study was described as very important criteria enough of financial sources (which is seen as a very limited factor for SMEs).

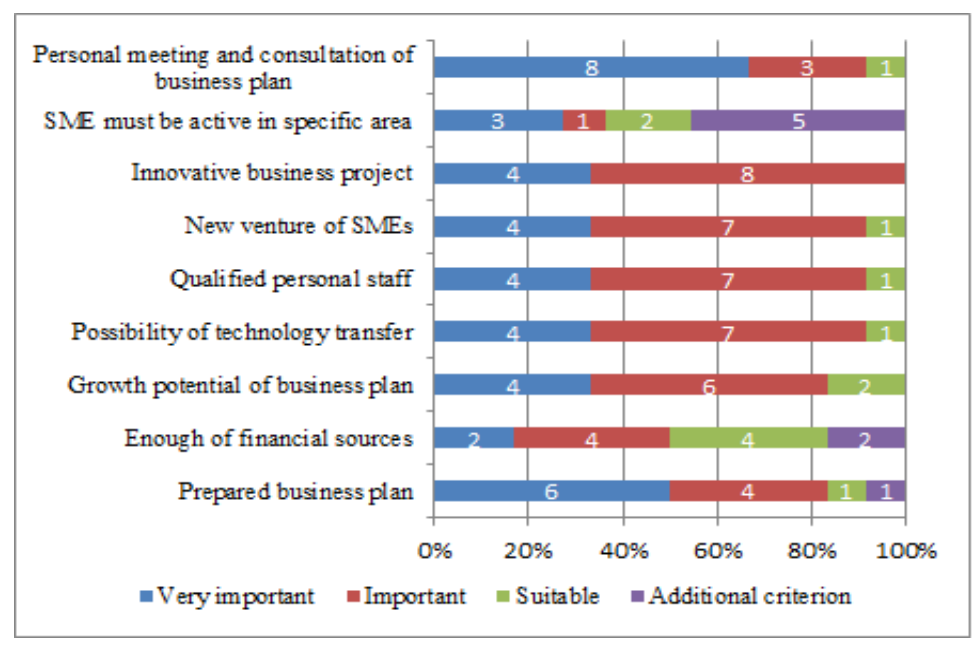

Figure 3: Entrance criteria

Following, in table 4 are summarized some of the gained best practices in area of entrance policy (own source, 2012, 2013),
(TCC Chemnitz, 2011), (CSES, 2002), UKBI (2003).

\section{Table 4: Best practices in entrance policy}

\begin{tabular}{|c|c|}
\hline \multicolumn{2}{|c|}{ Examples of Best of Practices - Entrance policy } \\
\hline Entrance policy - CZ & Entrance policy - Abroad \\
\hline $\begin{array}{l}\text { The situation in the Czech republic is quite } \\
\text { comparable to the EU standard. By some } \\
\text { Czech incubators is even the entrance policy } \\
\text { in a better condition than in the EU. In some } \\
\text { cases the Czech entrance policy has started }\end{array}$ & $\begin{array}{l}\text { For example the Technology Centre Chemnitz } \\
\text { (TCC Chemnitz) in Germany requires } 2 \\
\text { recommendations, one from the business } \\
\text { chamber and one from the TCC itself. In } \\
\text { Sweden in Mjärdevi must be applicant signed }\end{array}$ \\
\hline
\end{tabular}


with more individual approach by each applicant (for example Prague incubator Inovacentrum and TIC CKD), or Pilsen incubator - BIC. This approach is very close to approach in the United Kingdom (UK) where has been observed a redirection from formal criteria to informal.

\section{Observation: Evaluation Approach and Methods}

One of the most recent topics is a regular evaluation of incubation activities and their clients. The results show that incubators themselves are providing regularly some evaluation of their activities (58\%), following the evaluation of the incubated clients $(50 \%$ are regularly evaluated by incubators) or of graduates (no single graduate is regularly evaluated, only randomly $33,3 \%$ ) is unfortunately not very positive. It is also interested to see the most followed criteria. More than $60 \%$ of in university program (Entrepreneurial Development Program) in order to be considered as a suitable applicant. Another example of is Taguspark in Portugal which outsourced the entrance policy on the local business and innovation center which is using its own entrance methodology.

\section{Table 5: Best practices in evaluation}

\begin{tabular}{|c|c|}
\hline \multicolumn{2}{|c|}{ Examples of Best of Practices - Evaluation } \\
\hline $\mathbf{C Z}$ & Abroad \\
\hline $\begin{array}{l}\text { Probably more developed methods are } \\
\text { possessed by JIC which launched an } \\
\text { evaluation system Blues based on the } \\
\text { benchmarking method. Recently, the JIC } \\
\text { should be in the closest contact with graduate } \\
\text { clients. Blues system was also tested by } \\
\text { another } 2 \text { incubators (in Hradec Kralove and } \\
\text { in Olomouc). Similar system launched also an } \\
\text { incubator in Zlin (Technology Innovation } \\
\text { Centre). }\end{array}$ & $\begin{array}{l}\text { In the EU there are generally defined criteria } \\
\text { for evaluation in the publication Interim and } \\
\text { Ex Post Evaluation of EU Expenditure } \\
\text { Programs. In the book there can be found the } \\
\text { most monitored criteria also within the } \\
\text { incubated clients and graduates. In Germany } \\
\text { was first Sternberg (OECD, 1999) who realized } \\
\text { the call for evaluation and created a method of } \\
\text { graduate's evaluation. Currently in Germany } \\
\text { there is probably the best known system } \\
\text { launched by Association for Innovation, } \\
\text { Technology and Entrepreneurship with } \\
\text { approximately } 75 \text { evaluating criteria. In the } \\
\text { United Kingdom UK Business Incubation } \\
\text { Association has a strong influence which } \\
\text { recommends a chosen tool of evaluation } \\
\text { including a quality exit strategy for the } \\
\text { incubated clients. }\end{array}$ \\
\hline
\end{tabular}

Based on the gained data and experts' discussion it was possible to make the following conclusions regarding the incubators' evaluation:

- Evaluation system of incubators and their clients is very weak. Evaluation incubators make evidence about occupancy rate, financial performance of incubator, number of created work places by clients and number of employees in incubated enterprises. Other indicators such as survival rates of graduates clients on market, or turnover of incubated or graduates clients are evaluate only randomly. As we can see, evaluation practices are not well developed in Czech conditions, possibly best practices examples in table 3 can be an inspiration (own source, 2010), CSES (2002), (UKBI, 2003).

cor system by graduates almost does not exist.

- When making evaluation, it is mostly a limited method usually only focusing on monitoring some indicators (such as number of clients, created work places, etc.). 
- Evaluation method must present more complex and sophisticated issue using not only quantitative, but also qualitative data. A periodical contact with clients (also ex -clients) must be integrated into such methods.

- Incubator's management recognized raising awareness of this problematic.

- The impact to entrepreneurship can't be proved unambiguously because of the lack of data. (Tausl Prochazkova, 2012), (Tausl Prochazkova, 2013).

\section{Conclusion}

United Kingdom is one of the well-known countries with many business incubation activities. Perhaps the most important incubation institution in the UK - UK Business Incubation (UKBI, 2003) has published several recommendations for business incubator management. There are several processes described which should be followed by an incubator. One of the recommendations is about setting an effective system of management processes and regularly monitoring and touch with clients, ex-clients. Only so, can be formed an appropriate method of measuring incubation performance and impact to entrepreneurship growth. Also, another help to build a high-quality monitoring system and proved clearly a connection to entrepreneurship growth is to cooperate with statistical offices and use their data about enterprises demography. Unfortunately, based on the research made by the Czech statistical office (Tausl Prochazkova, 2012) the evidence of enterprises demography - birth, death - is a little bit patchy - and there is a lack of complete data about this topic.

The aim of this paper was to bring into focus the topic of business incubation and its impact on the small and middle sized companies. As it was mentioned, SMEs fight a number of issues and achieving an economic, social and environmental balance can be very difficult for them. One of the possible help in order to enable them raise their competitiveness and finally ensure a sustainable grow is seen in the concept of business incubation. Business incubation model has recently experienced increased attention as a model of start-up facilitation. Discussion about relationship between SMEs and business incubation opens a platform for further research. Currently, the lack of methodology to evaluate the impact of such business support tool was realized. Generally, there is no doubt about the incubation positive influence of incubation on the start-up ventures. However, more detailed information about the size and width of such impact is missing. Available sources which mainly exist are not compact enough. There are several recommendations and proposed models by various institutions related to business incubation but without any clear and universal conceptual framework. In order to understand the "added value" of business incubators there is a need for detailed research exploring the characteristics and performance of incubators themselves and (ex) firms located within. In this paper, it is a summary of an overarching incubator model that synthesizes elements and the best practices of incubation activities. As it is clear, the evaluation of contribution of these institutions to entrepreneurial activities, regional or national competitiveness and sustainability is a topic of a tremendous interest which calls for further research and studies.

\section{Acknowledgment}

This paper was created within the project SGS-2014-040 Modern practices in innovation, entrepreneurship and company management and within the support of the Motivation System of University of West Bohemia, part POSTDOC.

\section{References}

1. Aernoudt, R. (2004) "Incubators: Tool for Entrepreneurship?" Small Business Economics. 23 (2), 127 - 135.

2. Audretsch, D. (1995) Innovation and Industry Evolution. Cambridge: MIT Press.

3. CSES. (2002) "Benchmarking of Business Incubators." Centre for Strategy \& Evaluation Services. [Online], [retrieved July 10, 2011], http://www.cses.co.uk. 
4. European Commission (2010) "Putting Small Businesses First." [Online], [retrieved December 12 , 2011], http://ec.europa.eu/enterprise/newsroom /cf/itemshortdetail.cfm?item_id=3325.

5. European Union. (2010). "The Smart Guide to Innovation - Based Incubators (IBI)." [Online], [retrieved March 12, 2012] http://bookshop.europa.eu/en/the-smartguide-to-innovation-based-incubators-ibi-pbKN3210217/

6. Galloway, L. and Brown, W. (2002) "Entrepreneurship education at university: a driver in the creation of high growth firms?" Education + Training. 44 (8/9), $.389-405$.

7. Growlink. (2011) Growlinkg [Online], [retrieved April 12, 2012], http://growlink.se/en.

8. Horova, M. (2012) "Performance Audit Considering the Sustainability: Approach of the Czech Enterprises." Proceedings of the 8th European Conference on Management, Leadership and Governance. Reading: Academic Publishing International Limited, ISBN 978-1-908272-76-8, 8 - 9 November 2012, Pafos, Cyprus, 231-236

9. Januska, M., Kurkin, O., Miller, A. (2010) Communication environment for small and medium enterprises. Business Transformation through Innovation and Knowledge Management. International Business Information Management Association (IBIMA), ISBN: 978-09821489-3-8, 23 - 24 June 2010, Istanbul, Turkey, 217-226.

10.Kuratko, D. and LaFollette, W. (1987) "Small Business Incubators for local Economic Development." Economic Development Review. 5 (2), 49-55.

11.Lalkaka, R. (2000) Assessing the Performance and Sustainability in Mediterranean Countries. International Centre for Science \& High Technology, December 4 - 6, 2000, Trieste, Italy.

12.Lalkaka, R. and Abetti, P. A. (1999) "Business Incubation and Enteprise
Support Systems in Restructuring Countries. Creativity \& Innovation Management. 8 (3), 197 - 209.

13.Lucas, R. (1978) "On the size distribution of business firms." Bell Journal of Economics. 9, (2), 508 - 523.

14.Mole, K. (2004). "System of Theory and the Common Sense View of Advisors." Journal of Small Business and Enterprise Development.11(1), 114 - 120.

15. Network for Business Sustainability. (2013) SME sustainability challenges 2013. Online], [retrieved February 24. 2013], http://nbs.net/wp-content/uploads/NBSSME-Challenges-2013.pdf.

16.0ECD (1999) Business Incubation International Case Studies. Paris: OECD Publications Service.

17.Parker, S. (2009) The Economics of Entrepreneurship. Cambridge: Cambridge University Press,

18.Richard, D. (2008) "Small Business and Government", The Richard Report. [Online], [retrieved August 17, 2010], http://www.bl.uk/bipc/pdfs/richardrepor t2008.pdf.

19.Sobel, R (2008) "Testing Baumol: institutional quality and the productivity of entrepreneurship." Journal of Business Venturing, 23 (6), 641-655.

20.Storey, D. (1994) Understanding the Small Business Sector. Cengage Learning EMEA

21.Tausl Prochazkova, P. (2012) "Podnikatelský inkubátor jako nástroj podpory malého a středního podnikání." $E$ + M. Ekonomie a Management, Vol. 15 (3), 91-107.

22.Tausl Prochazkova, P. (2014) "Podnikatelský inkubátor a malý a střední podnik: spojení know-how a profesionální pomoci." Peer -Reviewed Conference Proceedings, Part III. ISBN 978-80-7435368, 4 - 5 February, 2014, Hradec Králové, Czech Republic, .322-328. 
23.Technologie Centrum Chemnitz, TCC. (2011) Technologie Centrum Chemnitz. [Online], [retrieved November 10, 2011.], http://www.tcc-chemnitz.de.

24.Schwab, K. (2013) "The Global Competitiveness Report 2013 - 2014." Geneva: World Economic Forum, 2013.

25.UKBI (2003) "Quality Benchmarks for Business Incubators." [Online], [retrieved June 11, 2011], http://www.sfedi.co.uk.
26.Wilber, Patti; Dixon, Leonard. (2003) "The Impact of Business Incubators on Small Business Survivability." [Online], [retrieved March 7, 2014.], http://www.sbaer.uca.edu/research/asbe/ 2003/pdfs/hub/07Wilber\&.pdf.

27.Wolfe, Ch., Adkins, D. and Sherman, H. (2000) "Best Pactices in Business Incubation" [Online], [retrieved November 11, 2011], http://www.marylandtedco.org/_media/p df/ted coprograms/NBIA_BestPracticesRep ort.pdf. 